\title{
Recent Trends In Manpower Development In The Southeast
}

\author{
Earle C. Traynham, JR.*
}

\section{INTRODUCTION}

In December, 1973, the Compenhensive Employment and Training Act (CETA) was signed into law, inaugurating a new and significant phase in our national manpower program. Referred to as the first special revenue sharing law, CETA provides federal funds to states, as well as cities and counties of 100,000 population or more. CETA replaces categorical grants used for manpower programs and allows a prime sponsor ${ }^{1}$ to allocate its funds according to what it considers are the needs of the area it serves.

A chronic problem of earlier manpower legislation stemmed from the fact that there were several acts, such as the Manpower Development and Training Act (MDTA) of 1962 and the Economic Opportunity Act, each with its own guidelines and designated categories eligible for manpower funds. CETA replaces virtually all existing manpower legislation and is, by far, the single most important source of manpower funds. A second problem with prior manpower acts concerned the determination of manpower needs and criteria for eligibility at the national level. Despite similarities among urban problems, vast differences often exist among communities both in terms of their particular manpower needs and in their ability to provide certain types of manpower services. At the local level, manpower programs were often designed to meet federal requirements rather than the community's needs. CETA shifts both the resources and the responsibility for manpower planning to the state and local level, providing only a minimal amount of federal direction. It provides state and local governments with the flexibility to tailor a comprehensive manpower program best suited to their needs.

It is the aim of this paper 1) to examine the Comprehensive Employment and Training Act, noting its strengths and weaknesses, and 2) provide some insights into our national manpower efforts in the first year of implementation of CETA. Part I briefly describes and evaluates the Act. In Part II, selected Manpower Plans in the Southeast are examined with the intent of determining how federal funds are being utilized and what groups are being served by manpower programs. Also, an attempt is made to evaluate the performance to date of local governments receiving CETA funds.

\footnotetext{
*Associate Professor of Economics, University of North Florida, Jacksonville, Florida.
} 


\section{CETA}

CETA contains seven Titles or major sections. Title I, the major title, describes a full range of manpower services eligible under the Act, including payment of allowances, support services such as health care and child care, assessment of manpower needs, public service employment, and others. Also included in Title I are general guidelines to be followed by a prime sponsor in drawing up its comprehensive manpower plan.

Prime sponsors must submit their comprehensive manpower plans to the Secretary of Labor for approval. Even though certain guidelines must be met, the prime sponsor is given full responsibility for determining manpower needs and which types of services should be provided.

Title II of CETA provides for additional federal funds to be made available for public service employment programs to areas of substantial unemployment. An area of substantial unemployment is defined as "any area of sufficient size and scope to sustain a public service employment program and which has a rate of unemployment equal to or in excess of 6.5 per centum for three consecutive months as determined by the Secretary." According to current interpretation, an "area" may range in size from a single census tract to a city or county.

Under Title III, the Secretary is empowered to provide funds for manpower services to segments of the population that are in particular need of such services. Examples of such target groups are youth, offenders, persons of limited English-speaking ability, older workers, Indians, and migrant workers. The remaining four Titles of CETA provide for the establishment of a Job Corps (Title IV), create a National Commission for Manpower Policy (Title V), create a new Public Service Job Program (Title VI), and explain some general provisions of the Act (Title VII).

It appears that CETA is the most comprehensive, yet flexible, manpower act ever passed by Congress. It recognizes the necessity of having manpower programs designed by the same unit which must administer the programs and deliver the manpower services. Furthermore, by making the funds available on a non-categorical basis, CETA gives much needed flexibility not just in planning but also in reprogramming manpower funds. Prior to CETA, if funds were shifted, for whatever reason, out of a particular manpower program, for example, MDTA, they could only be used for other pre-specified programs authorized under MDTA. This often resulted in a less than efficient use of funds. Under CETA, funds can be reprogrammed out of less efficient programs into higher priority uses without regard to category. Additionally, it allows funds to be shifted in response to changes in labor market conditions.

This shift of responsibility to the state and local level is not without some disadvantages. There are many, hopefully short-run, organizational problems related to the implementation of CETA. The vast majority of local governmental units eligible to become prime sponsors had no manpower program operational or planning responsibility prior to the 
passage of CETA. Faced with a time constraint of six months and very few federal guidelines, prime sponsors responded with a wide variety of administrative structures and often poorly trained staffs. Hopefully, time will ease some of these problems.

There are other problems which may be more persistent in nature. First, too little attention may be devoted at the local level to developing clear policies and guidelines to be followed in planning a comprehensive set of manpower programs. Secondly, merely giving the prime sponsor the capability of designing manpower programs which best serve the area's most pressing manpower needs does not insure that the prime sponsor will actually use its new authority for that purpose.

Many of the problems which existed prior to the enactment of CETA still exist. One such problem involves how best to allocate federal funds to prime sponsors. It is virtually impossible for the federal government to assess accurately the diverse needs of all the prime sponsors or the worthiness of each manpower program. On the other hand, formula allocation is sure to result in some funds being expended for programs of marginal value while other badly needed programs go wanting. A second problem stems from the budgetary process. Funding for manpower programs is one year at a time which hinders any attempts at long-range planning. Program goals and objectives must be geared to short-run attainment if the program is to be re-funded. A third major problem is the inadequacy of labor market data, especially at the local level. Insufficient data creates an even more acute problem now that the responsibility for planning rests almost totally with local governments. A fourth problem is the effect the local political process may have on the achievement of the purposes of the Act. It may be difficult for a chief elected official to make a commitment for the delivery of manpower services to the disadvantaged, unemployed, and underemployed if the voters react negatively to improved services for the disadvantaged. The inability or unwillingness of local governments to deal effectively with the problems of the disadvantaged is one of the primary reasons these groups turned to the federal government for assistance in the 1960's. Finally, there is the problem of a shortage of trained and qualified manpower administrators and planners which often translates into poor performance at the local level.

\section{SURVEY OF SOUTHERN MANPOWER PLANS}

\section{Allocation of Funds and Groups Served}

In spite of these problems, local governments have been generally successful in setting up and staffing Manpower Offices and developing comprehensive manpower plans. To get some idea how federal manpower funds are being applied in the Southeast, an examination is made of selected manpower plans for Title I grants. ${ }^{3}$ Very few prime sponsors were eligible in July, 1974, for funds under Title II (which provides 
funds for distressed area projects), and Title VI (under which funds are provided for public service employment programs) was not signed into law until December 31, 1974.

For this purpose, total expenditures are categorized in Table I according to program activities, by state. Table 2 reflects a breakdown of priority target groups being served by the prime sponsors. Some of the variations among states in expenditures for program activity and in target groups being served are noteworthy. However, totals for all states are more revealing of manpower activities in the Southeast.

As shown in Table 1, the two largest program activities are classroom training and work experience, accounting for 33.0 percent and 27.3 percent, respectively, of total expenditures. Of the remaining 39.7 percent of total expenditures, on-the-job training accounts for 15.9 percent, service to clients, 16.3 percent, while public service employment programs account for only 6.9 percent. The relatively large allocations for training and the small proportion of expenditures allocated for public service employment reflects the apparent optimism on the part of Southeastern manpower planners that job opportunities would exist for individuals who could upgrade their skill through manpower programs.

Although CETA requires that individuals served by manpower programs be economically disadvantaged and either unemployed or underemployed, prime sponsors are permitted to identify, within the broad category of eligible individuals, certain sub-groups which warrant special consideration. Generally, these target groups exhibit unusually high unemployment or underemployment rates or face substantially greater disadvantages in the labor market. Table 2 reflects the state and regional priorities of prime sponsors in the Southeast. The largest target group is youth, accounting for 30.2 percent of the total individuals to be served. Other significant target groups are: minorities (15.6 percent), women (7.3 percent), veterans (6.6 percent), and older workers (3.9 percent). General programs aimed at reaching the unemployed and underemployed account for 33.4 percent of the total individuals to be served.

Table 2 contains several interesting variations among Southeastern states. Although older workers represent 3.9 percent of the total individuals to be served, three of the eight states surveyed did not identify older workers as a target group. Four of the eight states surveyed did not report any programs aimed specifically at underemployed individuals. Only three states identified offenders as a target group, while only two had programs designed specifically to aid the handicapped.

Given the substantial differences which exist among the prime sponsors as to selection of priority target groups, a closer examination is made of the manpower plans to determine how target groups are selected. Ideally, prime sponsors should identify the size and composition of the civilian labor force, including the employed, the unemployed and underemployed populations in the prime sponsor's labor market. This data can then be used to identify those groups exhibiting a relatively high incidence of unemployed or underemployed. 
TABLE 1

MANPOWER EXPENDITURES BY PROGRAM ACTIVITY, BY STATE

(In Thousands of Dollars)

\begin{tabular}{|c|c|c|c|c|c|c|c|c|c|c|c|c|}
\hline State & $\begin{array}{c}\text { Classroom } \\
\text { Training }\end{array}$ & $\%$ & $\begin{array}{c}\text { On-The-Job } \\
\text { Training }\end{array}$ & $\%$ & $\begin{array}{c}\text { Pub. Serv. } \\
\text { Employment }\end{array}$ & $\%$ & $\begin{array}{c}\text { Work } \\
\text { Exper. }\end{array}$ & $\%$ & $\begin{array}{l}\text { Serv. to } \\
\text { Clients }\end{array}$ & $\%$ & $\begin{array}{c}\text { Other } \\
\text { Activities }\end{array}$ & $\%$ \\
\hline Alabama & 912 & 29.8 & 564 & 18.4 & 400 & 13.1 & 1041 & 34.1 & 140 & 4.6 & - & - \\
\hline Florida & 4597 & 32.0 & 2854 & 19.9 & 547 & 3.8 & 3468 & 24.1 & 2879 & 20.8 & 29 & 0.2 \\
\hline Georgia & 928 & 52.3 & 41 & 2.3 & 245 & 13.8 & 350 & 19.7 & 212 & 11.9 & - & - \\
\hline Kentucky & 1089 & 20.7 & 867 & 16.5 & 719 & 13.7 & 1683 & 32.0 & 857 & 16.3 & 45 & 0.9 \\
\hline Mississippi & 673 & 44.6 & 200 & 13.3 & 180 & 11.9 & 223 & 14.8 & 120 & 8.0 & 112 & 7.4 \\
\hline North Carolina & 946 & 46.1 & 370 & 18.0 & 137 & 6.7 & 483 & 23.5 & 116 & 5.7 & - & 一 \\
\hline South Carolina & 687 & 35.9 & 94 & 4.9 & - & - & 891 & 46.6 & 240 & 12.6 & - & - \\
\hline Tennessee & 876 & 35.9 & 163 & 6.7 & - & - & 697 & 28.5 & 706 & 28.9 & - & - \\
\hline TOTALS: & 10,708 & 33.0 & 5153 & 15.9 & 2228 & 6.9 & 8836 & 27.3 & 5270 & 16.3 & 186 & 0.6 \\
\hline
\end{tabular}

Source: Sample of 23 Comprehensive Manpower Plans for fiscal year 1975 for the eight southeastern states included in Region IV of the Department of Labor. 
TABLE 2

MANPOWER TARGET GROUPS, BY STATE

\begin{tabular}{|c|c|c|c|c|c|c|c|c|c|c|c|c|c|c|c|c|c|c|c|c|}
\hline State & $\begin{array}{c}\text { Older } \\
\text { Workers }\end{array}$ & $\%$ & Youth & $\%$ & $\begin{array}{l}\text { Unem- } \\
\text { ployed }\end{array}$ & $\%$ & $\begin{array}{r}\text { Underen } \\
\text { ployed }\end{array}$ & m- $\%$ & Veterans & $15 \%$ & Women & $\%$ & $\begin{array}{c}\text { Offen- } \\
\text { ders }\end{array}$ & $\%$ & $\begin{array}{l}\text { Hand } \\
\text { cappe }\end{array}$ & i- $\%$ & $\begin{array}{c}\text { Minor- } \\
\text { ity }\end{array}$ & $\%$ & Misc. & $\%$ \\
\hline Alabama & 75 & 3.6 & 725 & 35.1 & 144 & 7.0 & 150 & 7.3 & 109 & 5.3 & 525 & 25.4 & - & - & - & - & 240 & 11.6 & 100 & 4.8 \\
\hline Florida & 1484 & 5.0 & 8950 & 30.0 & 2456 & 8.2 & 5731 & 19.2 & 1819 & 6.1 & 935 & 3.1 & 266 & 0.9 & 352 & 1.2 & 7245 & 24.3 & 577 & 1.9 \\
\hline Georgia & - & - & 50 & 41.7 & - & - & - & - & 30 & 25.0 & 40 & 33.3 & - & - & - & - & - & - & - & - \\
\hline Kentucky & 60 & 0.9 & 1100 & 16.7 & 3300 & 50.2 & - & - & 670 & 10.2 & 985 & 15.0 & 165 & 2.5 & - & - & 300 & 4.6 & - & - \\
\hline Miss. & 54 & 2.9 & 820 & 44.7 & 290 & 15.8 & 620 & 33.8 & - & - & - & - & - & - & - & - & - & - & 49 & 2.7 \\
\hline N. Car. & - & - & 1071 & 61.8 & 55 & 3.1 & - & - & 95 & 5.4 & 220 & 12.7 & 33 & 1.9 & 25 & 1.4 & 233 & 13.5 & - & - \\
\hline S. Car. & 349 & 13.7 & 932 & 36.6 & 350 & 13.7 & - & - & 465 & 18.3 & 451 & 17.7 & - & - & - & - & - & - & - & - \\
\hline Tenn. & - & - & 2078 & 28.2 & 4078 & 55.4 & 230 & 3.1 & 237 & 3.2 & 628 & 8.5 & - & - & - & - & 110 & 1.5 & - & - \\
\hline TOTALS: & 2022 & 3.9 & 15,726 & 30.2 & 10,673 & 20.5 & 6731 & 12.9 & 3425 & 6.6 & 3784 & 7.3 & 464 & 0.9 & 377 & 0.7 & 8128 & 15.6 & 726 & 1.4 \\
\hline
\end{tabular}

Source: See Table 1 
With only one exception, the prime sponsors rely almost totally on 1970 census data to describe their labor market. In a few instances, attempts are made to update 1970 census figures. Unfortunately, census data provide little information pertaining to the composition of the employed, unemployed and underemployed populations in a local labor market. The result is that, with few exceptions, decision criteria are not made explicit in the manpower plans. Both selection of target groups and the relative importance of each target group reflected by the number to be served are based apparently only on intuition. Furthermore, even though Title I of CETA provides for the allocation of funds for the assessment of manpower needs, only two of the sampled manpower plans included projects aimed at providing insight into labor market needs.

\section{Reprogramming}

As mentioned in Part I, one of the primary advantages of CETA stems from the flexibility it gives the prime sponsor not only in planning, but also in reprogramming manpower funds. After making quarterly evaluations of all operating programs, the prime sponsor may reallocate remaining funds to improve the overall delivery of manpower services. Those programs operating at less-than-budgeted levels can provide funds for any of the other manpower programs which in the prime sponsor's opinion warrant additional funds. In addition, those programs aimed at providing skill training for occupations which are no longer characterized by labor shortages can be cancelled and the funds can be reallocated without restriction.

The ability to reprogram manpower funds without regard to expenditure category should be especially advantageous in the first year of CETA for at least two reasons. First, prime sponsors were asked to develop and submit for approval their manpower plans before all the planning and operating guidelines to be followed under CETA were developed. In fact, many manpower plans were not approved by the Department of Labor until after fiscal year 1975 had already begun. Secondly, and most importantly, fiscal year 1975 is witnessing rapidly changing labor market conditions. The national unemployment rate in July, 1974, was 5.3 percent. It currently stands at 8.7 percent and is rising. This very rapid increase in the number of unemployed creates a pressing need for public service employment programs and, at the same time, eliminates labor shortages in certain occupations. As Table I indicates, approximately 76 percent of total Title I expenditures were initially budgeted for some form of job training program and only 6.9 percent budgeted for public service employment. The recent deterioration in the labor market has likely changed these priorities substantially.

Since most reprogramming occurs only after mid-year evaluations of operating manpower programs, it is not possible to report the extent of reprogramming by each of the prime sponsors in the sample. However, 
much insight can be gained by examining in depth the efforts of one of the prime sponsors to reprogram its manpower funds. For this purpose, a prime sponsor representing a three-county consortium is selected, and its reprogramming activities are closely examined. The prime sponsor's initial budget of Title I funds was $\$ 2.9$ million.

In February, 1975, the prime sponsor submitted to the Department of Labor a revision of its manpower plan. The revisions include the creation of one new program, the expansion of six existing programs, and reductions in three programs. Approximately $\$ 294,000$ is reprogrammed. However, of the three program reductions, only one is based on a current evaluation of the program's inability to meet the needs of the local labor market. Due to a decline in the demand for carpenters and sheet metal workers, training classes for these occupations are cancelled, freeing up approximately $\$ 74,000$. For the most part, the remaining $\$ 220,000$ in reductions represents funds not needed because the Department of Labor has agreed to provide replacement funds for a summer youth employment program in the summer, 1975. Although several additional manpower programs are substantially below expected goals in terms both of expenditures and individuals served at the end of six months operation, the prime sponsor does not feel that any reduction in budgets is warranted. Of the toal $\$ 294,000$ in reprogrammed funds, $\$ 164,000$ is used to expand a year round youth employment programs. The remaining $\$ 130,000$ is used, almost totally, for training programs. None of the reprogrammed funds are utilized for public service employment programs. However, the prime sponsor is creating a large number of public service employment jobs out of Title I funds. Additional appropriations for Title I and a 10 percent bonus awarded to prime sponsors forming consortiums should provide approximately $\$ 550,000$ which will be used entirely for public service jobs for the remaining four months of fiscal year 1975. By utilizing these additional funds for public service employment, the prime sponsor will increase the number of public service job slots substantially.

\section{CONCLUSIONS}

Although these findings suggest that many of the potential improvements under CETA are not being realized, it is too early to pass judgement on the decentralization of manpower control. Only six months elapsed between the signing into law of CETA and the implementation date and most prime sponsors had little or no experience in manpower planning and program operation. Consequently, the first year of operation under CETA is very much a learning experience for prime sponsors. Rapidly rising unemployment has created additional problems for many Title I projects, and, at the same time, resulted in large Title VI grants requiring prime sponsors to establish and fill new public service employment programs. 
Hopefully, local governments will survive this "test by fire" and learn from their experience. Only the next few years will determine if CETA represents a step forward in developing our nation's manpower resources.

\section{FOOTNOTES}

1 Generally, a prime sponsor is any state government, any local government with a population of 100,000 or more persons, or any combination of local governmental units which encompasses 100,000 or more persons. Such combinations are referred to as consortiums. CETA encourages consortiums which cut across geo-political boundaries and conform more closely to a unified labor market.
2Public Law 93-203, 93rd Congress, S.1559, December 28, 1973, p. 13.

3 The sample consists of twenty-three comprehensive manpower plans covering Title I grants. In this paper, the Southeast conforms to region IV of the Department of Labor and consists of the following states: Alabama, Florida, Georgia, Kentucky, Mississippi, North Carolina, South Carolina, Tennessee. 